\title{
The Rise and Fall of the Yugoslav-Soviet Alliance, 1945-1948
}

Vojin Majstorović, University of Toronto

\begin{abstract}
This essay discusses the Yugoslav-Soviet relations from the end of the Second World War until early 1948, when Stalin expelled Tito from the international communist movement. The primary focus is on the interaction of Moscow and Belgrade's policies towards Albania, which until the middle of 1947 revealed the strength of the Yugoslav-Soviet relationship. Likewise, Stalin chose Albania to be the main frontline of the conflict when he turned against Tito. The demise of the Yugoslav-Soviet alliance, however, was not caused by the competition between Tito and Stalin for influence in Albania. Although Belgrade placed Moscow in the centre of its foreign policy by seeking the latter's approval and support for its expansionism, Kremlin's policies were dictated by considerations far greater than the bilateral ties between the two countries. When Soviet policy makers became convinced that the American commitment to Western Europe was permanent in the wake of the Marshall Plan, Kremlin decided to Stalinize the nascent communist bloc. In view of its popularity at home and assertiveness abroad, the Titoist regime was bound to be the primary victim of the Stalinization drive.
\end{abstract}




\section{Introduction}

This essay explores the causes of the Tito-Stalin split of 1948 and it makes three central arguments. First, Moscow elevated a solvable conflict with Belgrade over influence in Albania into a dispute over Marxist dogma because it did not want to be reconciled with the leadership of the Communist Party of Yugoslavia (CPY). Tito had an independent power base, which made him fundamentally incompatible with Kremlin-ordered Stalinization drive of communist governments of Eastern Europe. The aim was to replace relatively autonomous communists with completely docile leaders. The Stalinization of Eastern Europe was a Soviet response to the increased American threat to Moscow's hegemony in Eastern Europe after the Marshall Plan. Second, until Moscow opted to Stalinize the emerging communist camp, the Yugoslav-Soviet relations thrived and Belgrade did not welcome or anticipate an irrevocable break with Moscow.

The essay is organized into four parts. The first section deals with the historiography of the split. It situates my arguments in the existing schools of interpretation. The second part contextualizes Belgrade's drive to control Albania within the ambitious Yugoslav foreign policy, and it outlines the YugoslavSoviet relations vis-à-vis Albania until the summer of 1947. During this period, Belgrade's drive to subjugate Albania enjoyed Moscow's support and the Yugoslavs carefully coordinated their policies with the Soviets. The third part of the essay discusses the apex of the Yugoslav-Soviet alliance in the initial phases of the emerging Cold War in the summer and fall of 1947. The Marshall Plan threatened the Soviets, who responded by tightening their grip over Eastern Europe with the creation of Cominform. In this 
occurrance, Belgrade proved to be Moscow's most dependable and loyal ally. The fourth section of the essay covers the rapid deterioration of the Yugoslav-Soviet ties in the second half of 1947. The focus is again on Albania, and the paper outlines how Moscow successfully dispelled Belgrade's influence in that country. The Kremlin abandoned its previous policy of allowing Yugoslavia a free hand in Albania because of the emerging Cold War and its plans to Stalinize Eastern Europe.

\section{Historiography: The Yugoslav Propaganda, Traditionalists and Revisionists}

Yugoslav propaganda claimed that the Kremlin always sought to subdue Yugoslavia ideologically, economically and politically. The conflict was inevitable as the socialist Yugoslavia was bound to reject such an exploitative partnership. The CPY were staunch communists, but from 1941, they grew increasingly disillusioned with Moscow. Marshal Tito had had enough of Soviet imperialism by 1948, and he decided to resist Stalin's encroachments on Yugoslav sovereignty. The basic aim of the official Yugoslav narrative was to minimize Tito's Stalinist past and to conceal Yugoslavia's imperial ambitions in the Balkans as an important feature of the split. With archives closed off, the traditionalist scholars echoed Titoist propaganda insofar as they were forced to rely on Yugoslav sources. Almost exclusively, these included documents published by the Yugoslav government, interviews with leading CPY officials, newspaper articles, and memoirs of leading Yugoslav communists. 
All traditionalists argued that the split was inevitable, as Tito's regime was too independent to be run by Moscow as a mere satellite. As evidence of this, they seized upon real or imagined disagreements from 1941 as proof of the looming rupture. Many of the causes of the split, which traditionalists cited, were entirely manufactured by Belgrade. Relying on interviews with Tito, Hamilton Armstrong claimed that when Stalin agreed to supply the Yugoslav army with modern military hardware in 1946, Tito saw this as a Soviet attempt to transform his army from a guerrilla force into an auxiliary of the Red Army. ${ }^{1}$ Yugoslavia came close to war with the United States over a Yugoslav-Italian border dispute in 1945 , and it is inconceivable that Tito would not have welcomed modern military equipment.

Ernest Halperin contended that Tito was a Left Deviationist in a secret alliance with Andreii Zhdanov, a Soviet politburo member and a Left Communist. ${ }^{2}$ In Halperin's scheme, Stalin was a bureaucrat who relied on the state to defend the interests of the revolution, and the expulsion of the Yugoslav Communists from Cominform was a double victory for Stalin against his external and internal opponents. ${ }^{3}$ Phyllis Auty argued that Belgrade was genuinely afraid that Moscow might try to annex Yugoslavia. She had three sources for this claim: Tito, Edvard Kardelj, one of Tito's most trusted deputies, and Moša Pijade, Tito's ideological tutor. ${ }^{4}$ There was no real evidence for

\footnotetext{
${ }^{1}$ Hamilton Armstrong, Tito and Goliath (New York: The Macmillan Company, 1951), 53.

2Ernst Halperin, The Triumphant Heretic: Tito's Struggle Against Stalin

(Portsmouth: Heinemann, 1958), 52.

${ }^{3}$ Ibid, 60.

4 Auty, 293. 
these claims. Auty was duped by well-organized Yugoslav propaganda.

Traditionalists, however, were also able to identify real sources of tension in the Yugoslav-Soviet relationship, although they often exaggerated their significance in the final analysis of the split. Armstrong claimed that the dispute over Trieste between Yugoslavia and Italy led to first threat of Stalin's excommunication of Tito, when the latter complained about Stalin's lack of support for the Yugoslavs. ${ }^{5}$ It is true that the Soviets were dissatisfied with Yugoslav assertiveness when it came to Trieste, but they never threatened to renounce Tito over the border dispute. 6

Adam Ulam astutely identified Tito as one of the most ardent Stalinists in Eastern Europe, positing that there were three fundamental causes of the conflict. The insufficient Soviet aid to Partisans during the war, Soviet attempts to subvert the Titoist regime by planting spies in the Yugoslav Army and the CPY, and Soviet failure to endorse a Balkan confederation. ${ }^{7}$ While Yugoslav leadership may have believed that Soviets did not provide adequate assistance to the Partisans, this did not play a role in the conflict in 1948. Likewise, it is likely that the Soviets tried planting spies in Yugoslavia, which undoubtedly irritated the CPY leadership, but no scholar working in either Yugoslav or Soviet archives has demonstrated a link between this and the split. Yet, Ulam was right to assert that the incompatibility of Belgrade and Moscow's Balkan policies played an important role in the split.

5 Armstrong, 65.

6 Tatiana Volokitina ed., Vostochnaia Evropa $v$ dokumentakh rossiiskikh arkhivov (Novosibirsk: Sibriskii khronograf, 1997), Document 240, 704-710.

${ }^{7}$ Adam Ulam, Titoism and the Cominform (Cambridge: New Haven: Harvard University Press, 1952), 71.

Past Imperfect

16 (2010) | @ | ISSN 1711-053X | eISSN 1718-4487 
Similarly, Auty correctly pointed out that Albania was run as a Yugoslav dependency until 1948, although she did not elaborate on Albania's role in the conflict. ${ }^{8}$ Instead, she explored the Soviet opposition to Belgrade's plans for the Yugoslav-Bulgarian federation as an important cause of the split. ${ }^{9}$

In contrast, by firmly grounding their scholarship in archival materials, revisionists challenged traditionalists on their central argument about the conflict's inevitability. They rejected that the Yugoslav-Soviet ties were encumbered with accumulating crises from 1941. Instead, revisionists believed that the periodic disagreements arising between the two sides, which traditionalists claimed were proof of the inevitability of the split, were always solved amicably and did not undermine the overall relationship.

Branko Petranović argued that the main cause of the conflict was Yugoslav plans for a Balkan federation, and he dismissed "as fantasy" the traditionalist argument that the genesis of the conflict could be traced to World War II. ${ }^{10}$ Leonid Gibianskii, the most prominent revisionist in English language literature, conceded that Trieste crisis caused tension between Tito and Stalin. However, in his view, this issue was smoothed over quickly. ${ }^{11}$ Tatiana Volokitina claimed that the meeting in Moscow in February 1948, when the Soviets forced Yugoslavs to sign an agreement stipulating that they would consult Moscow in foreign policy, was not the turning point in the relationship. This came only the following month, when in a speech to the Central

\footnotetext{
8 Auty, 292.

9 Ibid, 293.

10 Branko Petranović, Velika šizma: četrdesetosma (Podgorica: CID, 1999), 20-1

11 Leonid Gibianskii, "The Soviet-Yugoslav Conflict and the Soviet Bloc," in The Soviet Union and Europe in the Cold War, 1943-1953,eds. Francesca Gori and Silio Pons, eds., (London: Macmillan, 1996), 225

Past Imperfect

16 (2010) | @ | ISSN 1711-053X | elSSN 1718-4487
} 
Committee of the CPY, Tito openly defied Stalin. ${ }^{12}$ Similarly, Jeronim Perović agreed that Tito's policies towards Bulgaria in August 1947 upset Stalin because he was not consulted beforehand about Belgrade's actions, but he argued that this did not seriously impair "the extremely close bilateral relations". ${ }^{13}$

Revisionists' arguments were remarkably similar. They saw the Yugoslav-Soviet ties from 1944 to 1948 as very close, and they tended to highlight cooperation between Belgrade and Moscow. Gibianskii coined the term 'community of basic aims' to describe Moscow's and Belgrade's alliance.14 Volokitina argued that the ties were so strong between the two countries, that when the conflict erupted, it caught both the Soviets and the Yugoslavs by surprise. ${ }^{15}$ Perović believed that Yugoslavia served as a model for the other East European states in their internal development until late 1947.16 Undoubtedly, I.V. Bukharkin went furthest in advancing this argument, by naming his article "Konflikt, kotorogo ne dolzhno bylo byt" (Conflict which did not have to happen). ${ }^{17}$

This essay will argue for a synthesis of the two approaches. Traditionalists were correct to argue that there was a fundamental incompatibility between Tito and Stalin. That the CPY seized power on its own and that the regime enjoyed

12 Tatiana Volokitina, "Povodom 50-godišnjice početka sovjetskojugoslovenskog konflikta 1948. godine," in 1948. Jugoslavija i Kominform: Pedeset godina kansije, ed. Ranko Petković (Belgrade: Medjunarodna Politika, 1998), 163.

13 Jeronim Perović, "The Tito-Stalin Split: A Reassessment in Light of New Evidence," Journal of Cold War Studies Volume 9, No. 2, (Spring 2007): 36. ${ }^{14}$ Gibianskii, "The Soviet-Yugoslav Conflict and the Soviet Bloc,", 223.

15 Volokitina, "Povodom 50-godisnjice," 152.

16 Perović, 40.

17 I.V. Bukharkin, "Konflikt, kotorogo ne dolzhno bylo byt," Vestnik Minsterstva inostranih del, 6 (1990).

Past Imperfect

16 (2010) | @ | ISSN 1711-053X | elSSN 1718-4487 
widespread support in the country made Stalin likely turn on Tito eventually. Thus, traditionalists' central premise that Moscow could not control Belgrade as a satellite was correct. The CPY had its own ambitions, most notably in Albania, which it pursued doggedly. Yet, traditionalists failed to appreciate Tito's loyalty to Stalin, as well the degree to which Yugoslavia was dependent on the Soviet Union to achieve its foreign policy goals. With the archives closed, they were easily taken in by the Yugoslav propaganda that Tito was always wary of Soviets and that the CPY wanted to build socialism independently of Moscow. As long as Kremlin did not opt to Stalinize Eastern Europe, the SovietYugoslav alliance flourished. This explains why revisionists believed that the conflict erupted abruptly.

\section{Yugoslav-Soviet Relations vis-à-vis Albania until June 1947}

The CPY leadership was arrogant, assertive, ideologically inflexible, and most importantly, nationalist. The CPY united a fractured country around supranational South Slavic nationalism, and this was one of its main sources of legitimacy. Nonetheless, the Titoist regime was genuinely loyal to Stalin and the motherland of socialism, the USSR. Tito's sense of entitlement was great, but he saw himself as Stalin's junior partner. All of these characteristics of the Yugoslav leadership were reflected in Belgrade's foreign policy. Tito was careful to coordinate Yugoslavia's policies with Stalin, while at the same time aggressively pursuing his agenda with his great power patron.

The most important aspect of Belgrade's immediate postwar foreign policy was Tito's pursuit of unified Balkans 
dominated by Yugoslavia. Different factors shaped Belgrade's policies in Greece, Bulgaria and Albania, and Stalin's support for Yugoslavia's policies varied in these three countries. In Greece, Belgrade zealously supported the Communist Party of Greece (KKE)'s struggle to seize power through revolutionary means. ${ }^{18}$ In Bulgaria, Belgrade aggressively sought to incorporate Bulgaria into the Yugoslav Federation as its seventh constituent republic. ${ }^{19}$ The Soviets never fully endorsed Yugoslav expansionism in Greece and Bulgaria, although they never entirely rejected it. They advised KKK to apply more peaceful tactics, and they supported the Yugoslav-Bulgarian unification on the confederative model, which would have assured equality between the two states. ${ }^{20}$ This essay focuses on Albania as it was central to Belgrade's drive to dominate Southeastern Europe and because Albania was the main theatre of the Yugoslav-Soviet conflict in late 1947. Moreover, it was the only Balkan state where Belgrade's influence was decisive and where Yugoslav policies seemingly enjoyed Stalin's firm support.

On 9 January 1945, an important meeting took place between Stalin and Andrija Hebrang, one of the highest-ranking CPY officials. ${ }^{21}$ The aim of the meeting was for Yugoslavs to familiarize the Soviets with their territorial demands. In Hungary,

\footnotetext{
18 Ivo Banac, "The Tito-Stalin Split and the Greek Civil War," in eds. John O. Iatrides and Linda Wrigley, Greece at the Crossroads: The Civil War and Its Legacy (University Park: The Pennsylvania State University Press, 1995), 259. ${ }^{19}$ Nation Craig, "A Balkan Union? Southeastern Europe in Soviet Security Policy, 1944-1948," In Francesca Gori and Silio Pons, eds., The Soviet Union and Europe in the Cold War, 1943-1953 (London: Macmillan, 1996), 127.

${ }^{20}$ For Soviet opposition to Yugoslav expansionism in Greece see, Banac, "The Tito-Stalin Split and the Greek Civil War," 258-273 and Andrew Rossos, "The Incompatible Allies," The Journal of Modern History 69:1 (March: 1997): 42-76; for Soviet opposition to Yugoslav-Bulgarian federation, see Craig, "A Balkan Union? Southeastern Europe in Soviet Security Policy, 1944-1948”, 126-143 21Volokitina ed., Vostochnaia Evropa, Document 37, 118-133. 
the Yugoslavs wanted the city of Pecs, $\$ 900$ million worth of reparations, and a seat on the Allied Control Commission. From Romania, Yugoslavia sought the entire Banat region with the city of Timisoara, the second largest in Romania. In Austria, Belgrade aimed to annex the province of Carinthia. In Italy, Hebrang demanded the region of Istria, with all three major cities - Pula, Rijeka and Trieste. In Greece, the Yugoslavs wanted Aegean Macedonia (Northern Greece). Hebrang also announced that Bulgaria should be submerged in Yugoslavia, by joining the South Slav federation as one of its republics. With regards to Albania, Hebrang told Stalin that Albanians were Yugoslavs' best friends, and that the previous month Belgrade and Tirana had signed The Treaty of Friendship and Mutual Assistance.

The Yugoslav leadership was making territorial demands on all seven of its neighbors, and it had plans to annex three of them. ${ }^{22}$ Stalin was obviously annoyed, arguing that Yugoslavia would find itself in war with the entire world. This was no exaggeration. The war against Germany was still raging, and had the Soviets fulfilled any of the Yugoslav demands, especially

\footnotetext{
22 Yugoslavia dropped its claims against Romania and Hungary, most likely because they joined the emerging socialist camp. In 1946, the Yugoslavs were ordered by the Soviets to evacuate Austria and Tito complied. Ivo Banac, With Stalin against Tito: The Cominformist Splits in Yugoslav Communism (Croness: Cornell University Press, 1988), 17; The territorial dispute with Italy over Istria was eventually resolved in the Yugoslav favour. Belgrade received Pula and Rijeka, while only Trieste went to Italy. Tito was exceptionally aggressive when it came to Istria, and Yugoslavia came to the brink of war with the Americans over the issue. Jozo Tomasevich, "Yugoslavia During the Second World War," in Contemporary Yugoslavia: Twenty Years of Socialist Experiment, ed. Wayne Vucinich (Berkeley and Los Angeles: University of California Press, 1969), 110; The Yugoslav Army kept large number of troops on its border with Italy, and in the summer 1945, it shot down American transport airplanes over the disputed territories. Auty Phyllis, "Yugoslavia's International Relations (1945-1965)," in Contemporary Yugoslavia: Twenty Years of Socialist Experiment, ed. Wayne Vucinich (Berkeley and Los Angeles: University of California Press, 1969), 155. 
against countries which belonged in the British sphere of interest, the Grand Alliance would have been seriously jeopardized. The following day, Stalin confided to Georgi Dimitrov, the leader of the Bulgarian Communists, that Belgrade's demands were "unreasonable. I do not like the way they are acting...[Yugoslav leaders] are going too far". 23 Stalin gave evasive noncommittal responses to all of Hebrang's demands except in Albania. ${ }^{24} \mathrm{He}$ specifically approved of Belgrade's policies towards Tirana, adding that Yugoslavia had a responsibility to defend Albania against Great Britain.25 With this, Stalin effectively recognized Yugoslavia's dominance of Albania.

It is difficult to ascertain precisely why Stalin showed so much understanding for Belgrade's interests in Albania. There are several possible explanations, none of which are mutually exclusive. The Red Army, never advancing that far south, was unable to challenge Yugoslav wartime influence directly. Moreover, the Soviets were perhaps concerned that their Western Allies would be alarmed by their presence along Greece's Northwestern frontier. Finally, Stalin at the time trusted Tito to uphold his interests in Albania, and the Soviet leader saw no reason to undermine Belgrade's position.

23 Ivo Banac, ed., The Diary of Georgi Dimitrov, 1933-1949 (New Haven: Yale University Press, 2003), 353.

${ }^{24} \mathrm{He}$ advised the Yugoslavs to organize a committee of Macedonians in Northern Greece to legitimize Belgrade's demands for Aegean Macedonia. With regards to Istria, the Soviet leader jokingly offered to drown Yugoslavia's opponents in the Adriatic Sea, but he did not make any firm commitments. In response to Tito's drive for incorporating Bulgaria into Yugoslavia, Stalin told Hebrang that it was necessary to proceed slowly because of the Western Powers' concerns for Turkey. Moreover, he cautioned that the process of unification should go in stages. According to Stalin, there would have to be a pact of mutual assistance, followed by a confederation on the Austro-Hungarian model, and only then could gradual steps be taken towards complete unification. Volokitina ed., Vostochnaia Evropa, Document 37, 118-133 25 Volokitina, ed., Vostochnaia Evropa, Document 37, 118-133. 
The decisive influence of the CPY in Albania can be traced to the Second World War, when the Yugoslav Communists unified the fractious Communist Party of Albania (CPA), turning it into an effective partisan force. Throughout the occupation, CPY actively supported, advised and in some instances, guided the CPA-led resistance. After Albania's liberation, Tito sought to capitalize on his wartime influence. Essentially, Belgrade saw Albania as its own satellite, and a future republic of the Yugoslav Federation. According to Milovan Djilas, Tito intended to attach Kosovo and Metohija to the Albanian federal unit, in exchange for Tirana relinquishing its statehood. ${ }^{26}$

In the postwar years, numerous steps in the direction of unification were taken. The Albanian Army was financed from the Yugoslav Army's budget. From 1945-1948, Tirana received from Belgrade military equipment worth $704,791,400$ dinars. ${ }^{27}$ Moreover, Yugoslav military advisors were attached to the Albanian Army's Headquarters. By 1948, there were 600 Yugoslav advisors in Albania, and in turn, 2,000 Albanians were receiving training and studying in Yugoslavia. ${ }^{28}$ In July 1946, the Treaty of Economic Cooperation was concluded, and Belgrade granted Tirana 50 million dinar interest-free credit. ${ }^{29}$ In November, an agreement was signed, establishing a customs union and regulating the equalization of the two countries' currencies. According to the Albanian Deputy Prime Minister, the Yugoslav

\footnotetext{
26 Milovan Djilas, Vlast i Pobuna (Belgrade: Knjizevne Novine, 1991), 91-92. 27 James S. O'Donnell, A Coming of Age: Albania Under Enver Hoxha (New York: Columbia University Press, 1999), 20.

${ }_{28}$ Milorad Komatina, Enver Hodza iJugoslovensko-Albanski Odnosi (Belgrade: Novinsko-izdavačka ustanova, 1995), 74.

${ }^{29} \mathrm{Ibid}, 73$.
}

\author{
Past Imperfect \\ 16 (2010) | @ | ISSN 1711-053X | elSSN 1718-4487
}


assistance in 1947 represented 56.73\% of Albania's national budget. 30

Until the middle of 1947, as stipulated by Stalin at the meeting with Hebrang, the Soviet Union respected Yugoslavia's supremacy in Albania, by refusing to deal directly with the Albanians. For instance, during the summer of 1945, the Albanian government requested military aid from the Soviet Union. Moscow enacted a resolution to send shipments of arms via the Yugoslav government, giving Belgrade control over disbursement of the Soviet weaponry to Albanians. ${ }^{31}$ The Soviets were even straightforward towards the CPA that they considered Albania to be in Yugoslavia's sphere of influence. In June 1946, the Soviet ambassador in Belgrade, Anatolii Lavrent'ev, told Enver Hoxha, the General-Secretary of the CPA, that Tirana should strengthen its ties with Yugoslavia, since that would automatically mean stronger relations with the Soviet Union. ${ }^{32}$ Similarly, when Hoxha asked Molotov for assistance, the Soviet Foreign Minister told him that Yugoslavia stood between Albania and the USSR. ${ }^{3}$

Even Stalin referred to Tito's authority when Moscow had to deal Tirana. In May 1946, when Stalin asked Tito whether the Soviets should receive an important Albanian delegation, Tito responded: "we can take care of everything with them". Stalin agreed, "better if we help them through you". ${ }^{4}$ As late as 13

30 O'Donnel, A Coming of Age, 20.

${ }^{31}$ Leonid Gibianskii ed., "The Soviet Bloc and the Initial Stage of the Cold War: Archival Documents on Stalin's Meetings with Communist Leaders of Yugoslavia and Bulgaria," Cold War International History Project Bulletin 10, 126.

32 A.S. Anikeev, Kak Tito ot Stalina ushel: IUgoslav'ia, SSSR i SSHA v nachalnyi period "kholodnoi voiny"(1945-1957) (Moscow: Institut slavyanovodeniya RAN, 2002), 99.

33 Komatina, Enver Hodza, 47.

34 Gibianskii ed., "The Soviet Bloc and the Initial Stage of the Cold War," 122.

\section{Past Imperfect}

16 (2010) | @ | ISSN 1711-053X | elSSN 1718-4487 
December 1947, Lavrent'ev consulted Tito on bilateral trade between Albania and the Soviet Union, inquiring whether Belgrade would be opposed if Moscow was to deliver 5, 000 tons of oats to Tirana. ${ }^{35}$

\section{Zenith of the Yugoslav-Soviet Relations: Marshall Plan and Creation of Cominform}

The Soviet-Yugoslav alliance got a sudden and temporary impetus, when Kremlin decided to actively confront the United States. It is in the capacity of the 'sword of international revolution' that the idealistic Yugoslav leadership found itself at complete ease with their great power patron. Namely, when the Soviet Union was threatened by the Marshall Plan, and when it answered with corresponding tightening of its grip over the Eastern bloc through the creation of the Cominform, Belgrade proved to be Moscow's most enthusiastic ally. Simply, Tito's regime relished the opportunity to demonstrate its Communist orthodoxy and profound loyalty to Kremlin.

On 5 June 1947, the Marshall Plan was announced. Its aim was to stabilize the European economy, and thereby prevent the possibility of communist takeover of Western Europe. Moreover, the American policy makers sought to undermine the Soviet influence in Eastern Europe by tying the region economically to the West. ${ }^{36}$ Kremlin rejected participating in the Marshall Plan on

35 Tatiana Volokitina, ed., Sovetskii faktor v Vostochnoi Evrope 1944-1953: dokumenty $v$ dvukh tomakh, Volume 1, (Moscow: ROSSP-EN, 1999), Document 182, 512-513.

${ }^{36}$ Michael Cox and Caroline Kennedy-Pipe, "The Tragedy of American Diplomacy? Rethinking the Marshall Plan," Journal of Cold War Studies Vol.7, No. 1 (2005): 109 
2 July, after nearly a month of contemplating whether to partake in the American initiative. ${ }^{37}$ Participating in the Marshall Plan meant continuing the wartime alliance with the West, which precluded Stalinization of Eastern Europe. Its rejection, however, meant that Moscow would be freer to impose its will in the region. The Marshall Plan marked a turning point for Moscow in its relations with the Americans. As Scott Parrish explained,

The Marshall Plan...resembled an offensive attempt to undermine Soviet influence in Eastern Europe. This development created a much more threatening international environment. Fairly loose control over the region had been satisfactory when the Western power did not seem immediately threatening, and when selective cooperation with the West could deliver significant benefits. ${ }^{38}$

It is precisely in this threatening international environment that the Soviet- Yugoslav ties initially thrived. The Yugoslav government and media remained entirely mute on the Marshall Plan for two weeks after it was announced. 39 On 26 June, Belgrade sent a note to London, Paris and Moscow stating that "Yugoslavia is interested [in the Marshall Plan]...if it will ease economic recovery...and if it is based on United Nations

37 Geoffrey Roberts, "Moscow and the Marshall Plan: Politics, Ideology and the Onset of the Cold War, 1947," Europe-Asia Studies Vol. 46, No.8 (1994): 1376

38 Scott Parrish, "The Marshall Plan, Soviet-American Relations, and the Division of Europe," in The Establishment of Communist Regimes in Eastern Europe, 1944-1949, ed. Norman Naimark and Leonid Gibianskii, (Boulder: Westview Press, 1997), 285

39 Tripković, "Početak i eskalacija sukoba," 85. 
principles...."40 Yugoslavia was obviously very reluctant to embrace the American aid, although it did not reject it out of hand. At the time, Yugoslavia was in desperate need of foreign assistance as the regime was about to launch the Five Year Plan, and furthermore, not even Moscow had rejected the Marshall Plan yet. Thus, Belgrade's response can be qualified as very cautious and completely in line with Kremlin's views. The Yugoslav lack of enthusiasm must have comforted the Soviet leadership, as other East European countries reacted positively to the American proposal. ${ }^{41}$

With Soviets out of the way, Western powers invited communist-dominated governments of Eastern Europe to attend the Paris Conference on 12 July, with the aim of establishing multinational committees which would forward their requests for aid to Washington.42 According to Anna Di Biagio, virtually all Eastern European governments reacted positively, expressing an interest to participate at the Paris Conference. ${ }^{43}$ The communists of Eastern Europe were aware that the Marshall Plan was meant to tie them economically to West, thereby diminishing the Soviet influence in their countries. Nonetheless, unlike their Yugoslav comrades, they did not reject the offer of large scale assistance. Only Belgrade categorically refused to participate in the Paris Conference, making sure to fully coordinate their response with Moscow.

$40 \mathrm{Ibid}, 86$.

41 Cox and Kennedy-Pipe, "The Tragedy of American Diplomacy?," 122-3.

42 Anna Di Biagio, "The Marshall Plan and the Founding of the Cominform, JuneSeptember 1947," in The Soviet Union and Europe in the Cold War 1943-1953, ed. Francesca Gori and Silio Pons (London: Macmillan, 1996), 210.

43 Ibid, 211.

\author{
Past Imperfect \\ 16 (2010) | @ | ISSN 1711-053X | elSSN 1718-4487
}


On 4 July, the day that Belgrade received the invitation for the Paris Conference, the Yugoslav Minister of Foreign Affairs, Stanoje Simić, telephoned Lavrent'ev. ${ }^{44}$ Simić told the Soviet ambassador that the Yugoslav government wanted to give a negative reply but wished to confirm with Moscow the correctness of its stance. Apparently, Belgrade was quite anxious. Before the Soviets even had a chance to respond to Simić, Kardelj, a more senior official, also phoned Lavrent'ev. Kardelj informed him of the official Yugoslav decision that "Yugoslavia cannot participate in the Plan without the Soviet Union" because the governments of England and France sought to subordinate the economies of the smaller countries to the great powers, thereby stripping them of their independence. ${ }^{45}$ Moreover, Kardelj wanted the Soviets to respond promptly, so that Belgrade could publish its response the following day. The Yugoslav leadership was obviously bent on rejecting the Marshall Plan, but they also wanted to corroborate their stance with Moscow. Unsurprisingly, Kremlin fully endorsed Belgrade's position, and on 9 July, the Yugoslav media commenced an aggressive campaign against the American initiative. ${ }^{46}$

Kremlin's response to the Marshall Plan was the formation of the Cominform - an instrument by which the Soviets coordinated their control over the major European Communist parties. The Cominform's founding conference, which brought together nine European Communist parties at Szklarska Poręba in Poland from 22-28 September 1947, inaugurated an aggressive and confrontational policy with the West. The Yugoslav stance on

\footnotetext{
44 Volokitina ed., Sovetskii faktor, Document 164, 459-460.

45 Volokitina ed., Vostochnaia Evropa, Document 224, 668-9.

46 Tripković, “Početak i eskalacija sukoba,” 93. 
the Marshall Plan, which was in full accord with wishes of the Soviet leadership, was not forgotten, as the CPY was awarded a prominent role to play at Szklarska Poręba.

The Two-Camp thesis developed by Zhdanov at the Cominform's founding conference, proclaimed that the world was divided in two opposing and irreconcilable camps. ${ }^{47}$ One was the imperialistic and anti-democratic grouping of states led by America, and the other was the Soviet-led camp and its aim was the entrenchment of democracy and elimination of remnants of fascism. This meant, for the Western European Communist Parties, that the popular front had come to an end, as Zhdanov instructed the French and Italian Communists to defend their respective countries' independence by opposing the Marshall Plan. ${ }^{48}$ Eastern European parties were not ordered explicitly to embark upon the systematic Communization of their countries. However, the severe criticism of the gradualist approach to power, and the insistence on the irreconcilability between capitalism and communism, made it clear that Moscow was not willing to accept anything less than complete communist takeover of Eastern Europe. As a result, the Hungarian and Czechoslovak coalition governments were overthrown in the ensuing months.

The representatives of the CPY, Kardelj and Djilas, played a central role at Szklarska Poręba in signaling Moscow's policy shift to active confrontation with Washington. ${ }^{49}$ They led the barrage of criticism against those who represented the now-abandoned tactics of the popular front - the Italian and the French

47 Grant Adibekov, ed., Soveshchaniia Kominforma: 1947, 1948, 1949: dokumenty i materially (Moscow: ROSSPEN, 1998), 300-301.

48 Ibid, 302.

49 Ibid, 323-324. 
Communist Parties. The Yugoslav role of enforcers of Communist orthodoxy fit perfectly into the Yugoslav Communists' selfperception - ardently revolutionary and second only to the Communist Party of the Soviet Union (CPSU). The essence of their criticism of the French and the Italian communists was their censure of the parliamentary and peaceful path to socialism that the two Western Parties pursued. Concurrently, Djilas and Kardelj extolled the Yugoslav revolutionary achievements, which they claimed were made possible because the activities of CPY were modeled on the Bolshevik experience. As the leading Czech Communist Klement Gotwald noted, "the leaders of the Yugoslav Party always criticized us, they considered us to be opportunists, rightists. However, we did not argue with them, believing that they had greater achievements than us." 50

The Yugoslav-Soviet alliance was at its zenith after the Cominform's first conference. The Yugoslav leadership, needless to say, was beaming with delight. If Belgrade had doubts about its relationship with Kremlin at the time, it would have never rejected the Marshall Plan. Moreover, the Yugoslavs correctly perceived their role in Szklarska Poręba, as well as the establishment of the Cominform headquarters in Belgrade, as validation of their achievements and Moscow's appreciation of their support. Essentially, the zealous nature of the CPY was well suited for the emerging bi-polar world, which was rigidly divided between the Soviets and Americans.

The Soviets also seemed pleased with their Yugoslav allies at this time. The very fact that the CPA was not invited to the

50 Tatiana Volokitina, "Kholodnaia voina" i sotsial-demokratiia Vostochnoi Evropy, 1944-1948 gg. (Moscow: Russian Academy of Sciences Institute Slavyanovedeniya, 1998), 57. 
Cominform meeting demonstrated that Moscow still adhered to the agreement struck between Hebrang and Stalin which recognized Yugoslav predominance in Albania. Also, Zhdanov informed Stalin about the events that transpired at the conference from Poland. Evidently, he was quite happy with how the Yugoslav Communists carried themselves, saying that Kardelj and Djilas made a very satisfactory impression upon him. ${ }^{51}$ Moreover, in the conference's aftermath, the Soviet propaganda, including the important CPSU journal Bolshevik, reported very favourably on the Yugoslav policy. 52

Finally, in September 1947, the Foreign Policy Department (FPD) of the CPSU prepared a report on the CPY for the Soviet leadership. ${ }^{53}$ The FPD viewed Yugoslavia's foreign policy by and large positively. The strong anti-Western stance of the Yugoslav Communists and close friendship with, and gratitude to the Soviet Union was emphasized in the report. Although I have not seen the FPD reports on other communist parties, both Tatiana Volokitina and Leonid Gibianskii contend that compared to others, the CPY was characterized in an entirely favorable light. ${ }^{54}$ Nonetheless, the FPD also levelled some criticism at the tendency of the CPY to see itself as the leading party in the Balkans. More specifically, the FPD disapproved of the Yugoslav position on Albania, pointing out that Belgrade enviously guarded its influence there, looking unfavourably at the development of bilateral relations between Tirana and Moscow.

51 Sava Živanov, “Uzroci i Posledice Sukoba,” Jugoslovensko-Sovjetski Sukob 1948, ed. Petar Kačavenda, (Belgrade: Institut za Savremenu Istoriju, 1999), 24. 52 Gibianskii, "The Soviet-Yugoslav Conflict and the Soviet Bloc," 231.

53 Volokitina, ed., Vostochnaia Evropa, Document 240, 704-710.

54 Gibianskii, "The Soviet - Yugoslav Conflict and the Soviet Bloc" 227;

Volokitina, "Povodom 50-godisnjice," 156-7. 


\section{The Deterioration of Yugoslav-Soviet Ties and Competition}

for Albania

It is ironic that the increasingly tense international situation, which at first gave a powerful boost to the YugoslavSoviet ties over the Marshall Plan and creation of the Cominform, also created conditions for its rapid demise. Yet, despite the fact that relations between Belgrade and Moscow were seemingly strong, a series of events in the Balkans, as the FPD report had foreshadowed, irrevocably damaged a seemingly strong relationship. The cause of this rapid deterioration of relations was that after the Marshall Plan, Moscow's requirements in Eastern Europe changed. Previously, limited control of the region, which was achieved through communist governments or communist dominated coalition governments, was sufficient. However, as Washington's involvement in Europe increased, and concurrently, as relations between the Americans and the Soviets deteriorated, this was no longer the case. In the new explosive international environment, Stalin did not have confidence in Tito to execute his orders when the stakes were much higher.

The conflict between Yugoslavia and Soviet Union, in the months leading up to the final rupture, played out over who would control Albania. As has been noted, Moscow recognized Albania as Belgrade's protectorate. Nonetheless, from the middle of 1947, Kremlin began to undermine seriously Belgrade's influence in Tirana. The Yugoslavs resisted Moscow's encroachments in Albania, but significantly, they continued to seek Kremlin's approval for their policies until the very end, even when they violated Moscow's directives. Obviously, the CPY leadership 
believed that it was entitled to dominate the Balkans, but Belgrade never abandoned its Soviet ally.

The Soviets' first move in displacing Belgrade's influence in Tirana was to receive an Albanian delegation in July 1947, which complained about Yugoslavia's economic exploitation of Albania. ${ }^{55}$ Stalin told Hoxha that he disagreed with Belgrade's policies towards Albania, adding that as an independent country Albania should run its own foreign policy.56 The two countries concluded a Trade Agreement and Moscow sent its advisors to Albania. ${ }^{57}$ Kremlin had overhauled its previous policy of dealing with Tirana only through Belgrade.

The Yugoslav leadership, however, did not shrink from reasserting its position in Albania, although Belgrade sought to achieve this through cooperation with Kremlin. The Yugoslavs were aware that the CPA leadership was pursuing a policy of directly attaching itself to the Soviet Union at Yugoslavia's expense. ${ }^{58}$ Consequently, Tito protested against Moscow's new policy to Lavrent'ev. ${ }^{59}$ The Yugoslav leader told the Soviet ambassador that after Hoxha's visit to Moscow, several Albanian leaders began incorrectly assessing Belgrade's policy towards Tirana. Tito also said that he wanted to explain to the general secretary of the CPA that the Soviet aid to Albania should not be interpreted as Moscow's wish to separate Albania from Yugoslavia. Consequently, on 18 November, at Belgrade's urgings,

55 Volokitina, ed., Vostochnaia Evropa, Document 229, 677-681.

56 D.S. Chuvakhin,"S diplomaticheskoi missiei v Albanii," Novaya i noveyshaya istoriya. No. 51 (1995): 122.

57Leonid Gibianskii, "The Soviet-Yugoslav Split and the Cominform," The

Establishment of Communist Regimes in Eastern Europe 1944-1949, ed. Norman

Naimark and Leonid Gibianskii (Boulder: Westview Press, 1997), 294.

58 Komatina, Enver Hodza, 61.

59 Volokitina ed., Vostochnaia Evropa, Document 233, 687-688.

Past Imperfect

16 (2010) | @ | ISSN 1711-053X | elSSN 1718-4487 
the Albanian Politburo, including Hoxha, decided to improve relations with Yugoslavia ${ }^{60}$.

Tito's ploy worked as the seemingly pro-Yugoslav leadership in Albania prevailed. Having achieved this, Tito turned to Soviets to legitimize Belgrade's gains in Albania. On 13 December, Tito asked Lavrent'ev for Soviet views on Yugoslavia's plans to include Albania in its five-year plan and to introduce a single budget for the Albanian and the Yugoslav armies. ${ }^{61}$ Had the Yugoslav proposals been implemented, it would have amounted to annexation of Albania. At a meeting between Stalin and Djilas in Moscow on 17 January 1948, arranged specifically to settle the Albanian question, Stalin told Djilas that there was no divergence between Moscow and Belgrade on Albania. ${ }^{62}$

Evidently, Tito did not trust Stalin's assurances that Soviet and Yugoslav polices towards Albania were in harmony. Without consulting Moscow, Belgrade proposed to Tirana that Yugoslav military base should be opened in Southern Albania, in order to defend the country from the Greek 'Monarcho-fascists'.63 According to Djilas, Tito's unsurprising motive was to strengthen Belgrade's position in Albania vis-à-vis Moscow.64 On 20 January, Hoxha agreed to Belgrade's proposal. When the Soviets found out about the arrangement, they were enraged.

On 28 January, Molotov wrote to Tito that the British would interpret such an act as occupation of Albania, giving them

\footnotetext{
60 Ibid, Document 250, 735-737.

61 Volokitina ed., Sovetskii faktor, Document 182, 512-513.

62 Djilas, Conversations with Stalin (New York: Harcourt, Brace \& Wold, 1962)

87.

${ }^{63}$ Gibianskii, "The Soviet-Yugoslav Split and the Cominform”, 296.

64 Djilas, Vlast i Pobuna, 125.

Past Imperfect

16 (2010) | @ | ISSN 1711-053X | elSSN 1718-4487
} 
an excuse to interfere militarily in that country. ${ }^{65}$ Tito backed down, telling Lavrent'ev that if the Soviet Union wished, Yugoslavia would not send its troops to Albania. He added showing his increasing intransigence - "but in the event that Greece invades Southern Albania, Yugoslavia will have to swallow the bitter pill, not the Soviet Union." 66 On 1 February, Molotov sent an angry telegram to Tito. After ranting about the lack of consultation and the unwillingness of the Soviets to be put in front of a fait accompli, he concluded that there were serious differences between their countries.67 Molotov's harshly worded letter was the first direct indication of the impending conflict.

Consequently, on 10 February, a key meeting took place between the Soviets and the Yugoslavs in Moscow, officially prompted by the need to solve the Albanian crisis. ${ }^{68}$ The 10 February meeting was a crushing defeat for Tito's expansionist policies in the Balkans. The Yugoslavs were ordered to desist from sending armed divisions to Albania. As Stalin correctly noted, "the Yugoslavs are afraid that we would take away Albania from them".69 With this, any hopes that Belgrade may have still harbored for annexing Albania were also dashed, as the unification of the two countries was postponed indefinitely. Moreover, the Soviet leader said that Belgrade would never be allowed to incorporate Albania into Yugoslav federation as one of its republics.

\footnotetext{
65 Iuri Girenko, Stalin-Tito (Moscow: Izdatelstvo politicheskiih literaturi, 1991), 336 66 Ibid, 337.

67 Ibid, 337.

68 Banac ed., The Diary, 437-444.

${ }^{69} \mathrm{Ibid}, 441$.

Past Imperfect

16 (2010) | ( ) | ISSN 1711-053X | eISSN 1718-4487
} 
Also on the agenda on 10 February, were the bilateral relations between Sofia and Belgrade. The Soviets reverted to their old demand that Yugoslavia and Bulgaria should unify immediately according to the confederative model. This demand had been made repeatedly since 1945, however, Stalin for the first time ordered it forcefully. Stalin's seriousness may be inferred from his response to Dimitrov's inquiry about Soviet assistance to Bulgaria. The Soviet leader told him that Moscow would deal with that issue only when a joint Yugoslav-Bulgarian government put it forward. With regards to the Greek Civil War, Stalin said that the KKE could not win, and he ordered Belgrade and Sofia to curtail their aid to the communist insurgents.

Belgrade's ultimate reaction was to defy Stalin's orders on Greece, Albania and Bulgaria. On 21 February, Tito told the general secretary of the KKE that Yugoslavia would continue supporting the Greek Communists. ${ }^{70}$ In late February, the CPA leadership was again pressured by the Yugoslavs to raise with Moscow the issues of stationing Yugoslav troops in Southern Albania and of the unification with Yugoslavia. ${ }^{71}$ At a plenum of the Central Committee of the CPY on 1 March, Tito declared, "we must firmly hold onto Albania, we invested too much...we have a right to control what Albanians do, what agreements they conclude."72 Tito also spoke of the Bulgarian Party as a "trojan horse" for the CPY, and he repeated his opposition to a dualist federation. Eight days later, demonstrating that Belgrade was serious about its rebellion against Moscow, CPY banned party and

70 Gibianskii, “The Soviet-Yugoslav Split and the Cominform," 298.

71 Ibid, 298.

72 Vladimir Dedijer, ed., Novi Prilozi za Biografiju Josipa Broza Tita. Vol. 3, (Belgrade: Radna Organizacija “Rad”, 1984) 303-308.

Past Imperfect

16 (2010) | @ | ISSN 1711-053X | elSSN 1718-4487 
state officials from giving information to the Soviet advisors that pertained to Yugoslavia's economic situation. ${ }^{73}$

Moscow's reaction was ruthless and typical of Stalin when challenged by a subordinate. On 27 March, Stalin and Molotov sent a letter to the Central Committee of the CPY accusing the Yugoslav party leadership of being anti-Marxist.74 In MarxistLeninist-Stalinist jargon, the charge of being 'anti-Marxist' was tantamount to an accusation of treason from which there could be no redemption. In effect, the Soviets elevated a solvable quarrel over influence in the Balkans into a fundamental disagreement over Marxist dogma. Thereafter, reconciliation between Tito and Stalin was impossible, as Tito's regime was forced to fight for physical survival.

\section{Conclusion}

From late 1944 to the middle of 1947, Yugoslav-Soviet relations were ostensibly strong. Although Stalin never fully endorsed Tito's expansionism in the Balkans, except in Albania, this did not undermine the overall relationship between the two countries. In addition to ideological compatibility, the Soviet Union remained the sole source of Yugoslavia's international support, and Belgrade was Moscow's most reliable ally in Europe. The cooperation between the two countries when the Americans launched the Marshall Plan, and the Yugoslav role at the Cominform's founding conference, testify to loyalty of the CPY to the Soviet Union.

73 Volokitina, "Povodom 50-godišnjice," 164.

${ }^{74}$ Banac, With Stalin agaisnt Tito, 43.

Past Imperfect

16 (2010) | @ | ISSN 1711-053X | elSSN 1718-4487 
Nonetheless, the lingering problem of the incompatibility of the Yugoslav and Soviet Balkan policies had to be eventually resolved. Namely, had Stalin tried to purge the CPY leadership, and a dispute between the two parties escalated into a conflict between the two countries, it carried the substantial risk of alarming the US into increasing its support for Western Europe, and interfering in Eastern Europe. However, as the Soviet leadership became resigned to the concentrated American involvement in Europe after the Marshall Plan was launched, this ceased being a crucial consideration. Moreover, as Soviet relations with the West swiftly degenerated into the emerging Cold War, Stalin came to view Yugoslav expansionism in the Balkans as a threat to his ability to control events that risked sliding into a war with Washington and London. That is why the conflict began brewing during the summer of 1947, and it boiled over in early 1948. Conditions for Stalin to rein Tito in were ripe. Now, Belgrade had to toe Moscow's line completely; Tito would not be allowed to incorporate Albania into Yugoslavia, and Tito's influence in that country was to be replaced, decisively, with Stalin's.

Additionally, I believe that Stalin actively began to think about Stalinization of Eastern Europe at this time. On the political level, Stalinization entailed replacing the region's communists with individuals whose fortunes crucially depended on Stalin, and whose servility to Moscow was unquestionable. This was a logical extension of the Communization process, which climaxed after the Cominform's founding conference, as it assured more effective control of Eastern Europe. Admittedly, no 'smoking gun' evidence has emerged which pinpoints the precise moment when Stalin opted for implementing this policy. Regardless of when the

$$
\text { Past Imperfect }
$$

16 (2010) | @ | ISSN 1711-053X | elSSN 1718-4487 
Stalinization drive was exactly conceived, Tito's power base in Yugoslavia made him incompatible with it. Yet, prior to this, the fundamental incompatibility between the two dictators did not prevent the development of close ties between the two states in other areas.

The suggestion that the Kremlin planned in advance the Stalinization of Eastern Europe and that Tito was bound to be the primary victim of this policy indicates that the dispute over Albania was not the cause of the conflict, but its symptom. If Stalin had full confidence in Tito's reliability in the first place, he would not have opposed Yugoslav predominance in the tiny Adriatic state. As it was, Albania simply represented the most convenient instrument for Stalin to bring Tito into order. Stalin's sudden personal intervention in the Yugoslav-Albanian relationship in July 1947, which reversed the previous Soviet policy of giving Belgrade a free hand in Tirana, makes sense only in this wider context.

Still, the devotion of the Yugoslav leadership to the Kremlin should not be doubted even in the initial stages of the conflict. The purpose of the Yugoslav defiance in February and March 1948 was to pressure Stalin to give Belgrade a free hand in its policy towards Albania. Undoubtedly, Tito was aware that he was heading towards a clash with Stalin, but this would not have been Belgrade's first conflict with Moscow. Previous clashes never resulted in the ejection of the CPY from the international communist movement. Titoist leadership could not have possibly conceived the full ramifications of the conflict - Yugoslavia's total estrangement from the Soviet Union and the socialist camp. In practical terms, everything that Tito strove for in foreign policy since 1944 could not have been obtained without Stalin's backing. 
Yugoslavia was also on the verge of war with the US, and Tito could not have possibly expected support from those quarters. In any case, Belgrade did not contemplate the prospect that the rupture with Moscow would become so great that it would have to rely on the West for survival. No scholar has unearthed any evidence from either Yugoslav or Western archives that prior to the split the Yugoslavs had solicited support from the noncommunist world. As Djilas admitted in one of his latest works, the Yugoslav Party never contemplated building socialism independently of Moscow until after the split. ${ }^{75}$

It must be then concluded that the responsibility for the conflict lies primarily with Stalin. It did not matter so much what policies Tito pursued, but who he was - although appointed by the Comintern and even though genuinely loyal to Stalin and the USSR, Tito matured into an independent and successful communist on his own. His legitimacy stemmed from the exploits of the CPY, and his rule was based on the broad support that he enjoyed in Yugoslavia. Likewise, Tito's grandiose ambitions in the Balkans, and assertiveness with which he pursued his aims, reflected his sense of entitlement. As a result, when the conflict with the West became a distinct possibility, Stalin decided to close ranks in the communist movement, instead of having to deal with a junior partner who stubbornly demanded his place in international communism.

75 Djilas, Vlast i Pobuna, 115.

Past Imperfect

16 (2010) | @ | ISSN 1711-053X | elSSN 1718-4487 


\section{Bibliography}

Primary Sources

Adibekov, Grant. ed. Soveshchaniia Kominforma : 1947, 1948, 1949: dokumenty i materially. Moscow: ROSSPEN, 1998.

Banac, Ivo. ed. The Diary of Georgi Dimitrov, 1933 - 1949. New Haven: Yale University Press, 2003.

Dedijer, Vladimir. ed. Novi Prilozi za Biografiju Josipa Broza Tita. Volumes 1 - 3. Belgrade: Radna Organizacija “Rad”, 1984.

Djilas, Milovan. Conversations with Stalin. New York: Harcourt, Brace \& Wold, 1962.

Djilas, Milovan. Vlast i Pobuna. Belgrade: Knjizevne Novine, 1991.

Gibianskii, Leonid. ed. "The Soviet Bloc and the Initial Stage of the Cold War: Archival Documents on Stalin's Meetings with Communist Leaders of Yugoslavia and Bulgaria, 1946 1948“. Cold War International History Project Bulletin 10. $112-134$.

Volokitina, Tatiana. ed. Sovetskii faktor v Vostochnoi Evrope 1944 1953: dokumenty $v$ dvukh tomakh. Volume 1. Moscow: ROSSP-EN, 1999.

Volokitina, Tatiana. ed. Vostochnaia Evropa $v$ dokumentakh rossiiskikh arkhivov, 1944 - 1953 gg. Novosibirsk: Sibriskii khronograf, 1997. 
Secondary Sources

Anikeev, Anatoliy. Kak Tito ot Stalina ushel : IUgoslav'ia, SSSR $i$ SSHA $v$ nachalnyi period "kholodnoi voiny"(1945-1957). Moscow: Institut slavyanovodeniya RAN, 2002.

Armstrong, Hamilton. Tito and Goliath. New York: The Macmillan Company, 1951.

Auty, Phyllis. Tito: a Biography. London: Longman, 1970.

------.“Yugoslavia's International Relations (1945-1965)”. In Contemporary Yugoslavia: Twenty Years of Socialist Experiment, ed. Wayne Vucinich, - 202. Berkeley and Los Angeles: University of California Press, 1969.

Banac, Ivo. With Stalin agaisnt Tito: The Cominformist Splits in Yugoslav Communism. Cornell: Cornell University Press, 1988.

Banac, Ivo. "The Tito-Stalin Split and the Greek Civil War". In Greece at the Crossroads: The Civil War and Its Legacy, ed. John Iatrides and Linda Wrigley, 258 - 273. University Park: The Pennsylvania State University Press, 1995.

Borozan, Djordje. "Albanija u Kampanji Kominforma Protiv Jugoslavije, 1948 - 1950." In Jugoslovensko - Sovjetski sukob 1948, ed. Petar Kačavenda, 49 - 58. Belgrade: Institut za Savremenu Istoriju, 1999.

Bukharkin I.V. "Konflikt, kotorogo ne dolzhno bylo byt." Vestnik Minsterstva inostranih del, no. 61990.

Chuvakhin, D.S. "S diplomaticheskoi missiei v Albanii." Novaya $i$ noveyshaya istoriya. No. 51 (1995)

Cox, Michael, and Caroline, Kennedy-Pipe. "The Tragedy of American Diplomacy? Rethinking the Marshall Plan." Journal of Cold War Studies, Vol. 7, No. 1 (2005)

Past Imperfect 16 (2010) | @ | ISSN 1711-053X | elSSN 1718-4487 
Craig, Nation. "A Balkan Union? Southeastern Europe in Soviet Security Policy, 1944 - 1948." In The Soviet Union and Europe in the Cold War, 1943 - 1953, ed. Francesca Gori and Silio Pons, 126-143. London: Macmillan, 1996.

Di Biagio, Anna. "The Marshall Plan and the Founding of the Cominform, June - September 1947." In The Soviet Union and Europe in the Cold War, 1943 - 1953, ed. Francesca Gori and Silio Pons, 208-221. London: Macmillan, 1996.

Gibianskii, Leonid. "The Soviet - Yugoslav Conflict and the Soviet Bloc." In The Soviet Union and Europe in the Cold War, 1943 1953, ed. Francesca Gori and Silio Pons 222 - 245. London: Macmillan, 1996.

Gibianskii, Leonid. "The Soviet - Yugoslav Split and the Cominform." In The Establishment of Communist Regimes in Eastern Europe, 1944 - 1949, ed. Norman Naimark and Leonid Gibianskii, 291-312. Boulder: Westview Press, 1997.

Girenko, Iuri. Stalin - Tito. Moscow: Izdatelstvo politicheskiih literaturi, 1991.

Halperin, Ernest. The Triumphant Heretic: Tito's Struggle Against Stalin. Portsmouth: Heinemann, 1958.

Komatina, Milorad. Enver Hodza I Jugoslovensko-Albanski Odnosi. Belgrade: Novinsko-izdavacka ustanova, 1995.

O’Donnell, James. A Coming of Age: Albania Under Enver Hoxha. New York: Columbia University Press, 1999.

Parrish, Scott. "The Marshall Plan, Soviet - American Relations, and the Division of Europe." In The Establishment of Communist Regimes in Eastern Europe, 1944 - 1949, ed. Norman Naimark and Leonid Gibianskii, 267- 287. Boulder: Westview Press, 1997.

\author{
Past Imperfect \\ 16 (2010) | ( ) | ISSN 1711-053X | elSSN 1718-4487
}


Perović, Jeronim. "The Tito-Stalin Split A Reassessment in Light of New Evidence." Journal of Cold War Studies, vol. 9, no. 2 (2007)

Petranović, Branko. Balkanska Federacija, 1943 - 1948. Belgrade: IKP Zaslon, 1991.

Petranović, Branko. Velika šizma: četrdesetosma. Podgorica: CID, 1999.

Roberts, Geoffrey. "Moscow and the Marshall Plan: Politics, Ideology and the Onset of the Cold War, 1947." Europe-Asia Studies Vol. 46, No.8 (1994)

Rossos, Andrew. "The Incompatible Allies." The Journal of Modern History 69:1 (March: 1997)

Tomasevich, Jozo. "Yugoslavia During the Second World War". In Contemporary Yugoslavia: Twenty Years of Socialist Experiment, ed. Wayne Vucinich, 59 - 118. Berkeley and Los Angeles: University of California Press, 1969.

Volokitina, Tatiana. "Kholodnaia voina" i sotsial-demokratiia Vostochnoi Evropy, 1944-1948 gg. Moscow: Russian Academy of Sciences Institute Slavyanovedeniya, 1998.

Volokitina, Tatiana. "Povodom 50-godisnjice pocetka sovjetskojugoslovenskog konflikta 1948. godine". In 1948. Jugoslavija i Kominform: Pedeset godina kansije, ed. Ranko Petković, 151 - 180. Belgrade: Medjunarodna Politika, 1998.

Ulam, Adam. Titoism and the Cominform. Cambridge: Harvard University Press, 1952.

Živanov, Sava. "Uzroci i Posledice Sukoba." In Jugoslovensko Sovjetski sukob 1948, ed. Petar Kačavenda, 21 - 34. Belgrade: Institut za Savremenu Istoriju, 1999. 